\title{
Effect of postglacial warming seen in high precision temperature log deep into the granites in NE Alberta
}

\author{
Jacek Majorowicz $\cdot$ Jan Šafanda
}

Received: 27 March 2014 / Accepted: 31 August 2014 / Published online: 11 September 2014

(C) Springer-Verlag Berlin Heidelberg 2014

Keywords Surface processes $\cdot$ Borehole temperatures . Climatic warming $\cdot$ Ice Age $\cdot$ Heat flow

\section{Introduction}

Recently reported new terrestrial heat flow density (referred further to as "heat flow") determination from a 2.36-km-deep well of opportunity (AOC Granite-Hunt well) drilled deep into some 2- to 2.4-Gyr-year old Precambrian basement rocks (Walsh 2013) just west of Fort McMurray, Alberta (see Figs. 1, 2 for location information), shows increase of heat flow with depth (Majorowicz et al. 2014). Cores were collected from granites, which are below $0.55 \mathrm{~km}$ and to the well bottom of $2.36 \mathrm{~km}$. This borehole was logged in June 2011, and several years after, it was drilled in 1994 and deepened in 2003. Therefore, it is assumed to be in thermal equilibrium. Temperature versus depth (Fig. 3a) shows a significant increase in the thermal gradient with increasing depth in the basement rocks (from $18{ }^{\circ} \mathrm{C} / \mathrm{km}$ at the top of granites to $21^{\circ} \mathrm{C} / \mathrm{km}$ at the bottom of the well; Fig. 3b). Amplitude of glacial-postglacial surface temperature change was at first assessed about $10{ }^{\circ} \mathrm{C}$ referred to present surface temperature of $5{ }^{\circ} \mathrm{C}$ and assessed the glacial base surface temperature during the last ice age at ( -4 to $5{ }^{\circ} \mathrm{C}$ ) (Majorowicz et al. 2012a). We

\footnotetext{
J. Majorowicz $(\square)$

Helmholtz-Alberta Initiative HAI4, Department of Physics, University of Alberta, Edmonton, AB, Canada

e-mail: majorowicz@shaw.ca; majorowi@ualberta.ca

J. Šafanda

Institute of Geophysics, Czech Academy of Sciences, Prague,

Czech Republic
}

now verify this estimate in this paper based on new information on heat production and thermal conductivity.

We also attempt to reconstruct surface paleotemperature history for the last $100 \mathrm{kyr}$ from functional space inversion (FSI) of the thermal data.

\section{Borehole temperature logs paleoclimatology}

The method how to reconstruct surface temperature history from inversions of precise temperature logs done in wells was pioneered earlier by Čermák (1971) and by Lachenbruch and Marshall (1986); (see: Bodri and Čermák 2007 for review and list of references on the subject). The method is based on the inversion of stabilized, high precision deep borehole temperature logs, which are in thermal equilibrium with surrounding rock. Deep down to some 2-km depth perturbation of the heat flow could be caused by warming since recent glaciations ending some 12-13 kyr ago in Canada (Ritchie 1983). Surface temperatures peaked in the Holocene Optimum 6-7 kyr ago known to be some $1-2{ }^{\circ} \mathrm{C}$ warmer than recent centuries temperature level (Kerwin et al. 1999). Perturbations observed down to $0.1-0.3 \mathrm{~km}$ are mainly related to the climate changes of the last 1-2 centuries (Pollack et al. 1998; Bodri and Čermák 2007; Rath et al. 2012) on large regional and continental scale. All these surface temperature changes influence the subsurface heat flow.

The method has been applied to reconstruct timing and amplitude of surface temperature change from latest glacial to postglacial climatic history through many areas in Eurasia and North America (Hotchkiss and Ingersoll 1934; Čermák 1971; Kukkonen 1993; Kukkonen and Šafanda 1996; Kukkonen et al. 1998; Mareschal et al.1999; Rolandon et al. 2003; Kukkonen and Joeleht 2003; Demezhko et al. 2007; Demezhko and Golovanova 2007; Majorowicz 


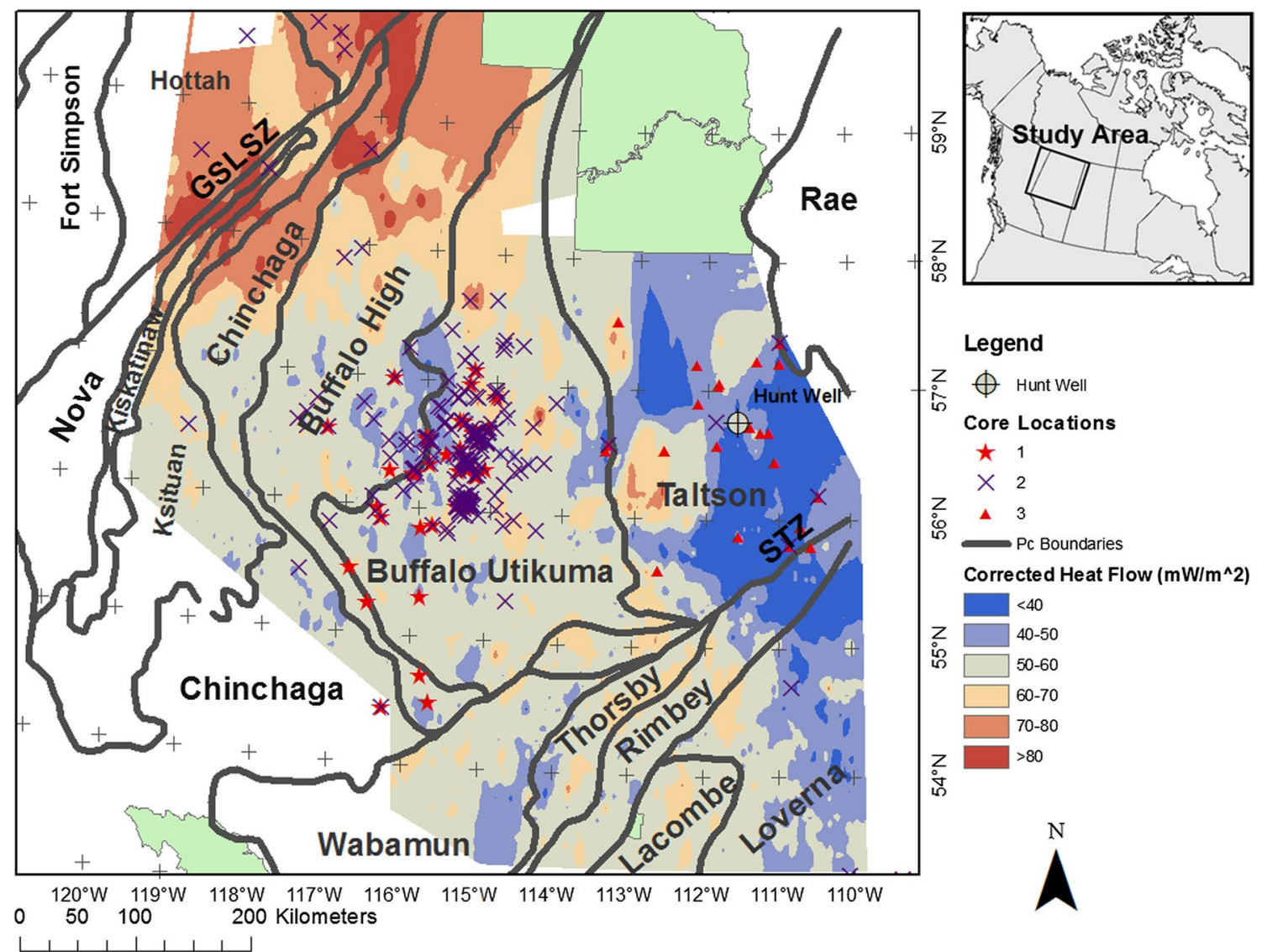

Fig. 1 Study area and the location of the Hunt well used in this study against heat flow pattern estimated by Majorowicz et al. (2014). Other elements shown are: Precambrian basement domains, boundaries, and lineaments (STZ is the Snowbird Tectonic Zone, GSLZ is the Great Slave Lake Shear Zone) are shown as thick black lines. National Parks (Buffalo in NW Alberta and Jasper in W Alberta) are

and Šafanda 2008; Chouinard and Mareschal 2009; Gosnold et al. 2011; Mottaghy et al. 2010; Majorowicz and Wybraniec 2011; Demezhko et al. 2013).

\section{Last ice age signature on temperature logs}

In the climate history of the last $20 \mathrm{kyr}$ in northern Canada and generally in the northern hemisphere, several periods are usually distinguished (IPCC 2007): the Last Glacial; Postglacial warming including more recent Holocene Optimum, Post-Holocene cooling (Ritchie 1983; Peltier 2002), and recent millennium. In recent millennium, we had Medieval Warm Period (MWP), Little Ice Age (LIA) and Recent Warming Period (RWP) (Grove 1988; Lamb 1965). Proxy data in western Canada exist, which covers Holocene history of climate. These include tree rings, which provide a spring-summer-based temperature history (Luckman et al. 1997; Luckman and Wilson 2005), lake shown in green. Well locations are as follows: (1) Wells with thermal conductivity and heat generation data from University of Alberta Geothermal Lab; (2) Wells with U and Th concentration determinations; (3) Location of wells where precise temperature $T$ measurements was made in the upper $300 \mathrm{~m}$ (modified from Majorowicz et al. 2014)

sediments focusing on the evolution of grain size (Campbell 1999) and pollen from upland lakes of Manitoba, Canada (Ritchie 1983).

Jessop (1971) assumed that the base of the glacier is near the pressure point of melting $\left(-1{ }^{\circ} \mathrm{C}\right)$. It seems to be confirmed in many cases of the deep well temperature profiles from the eastern part of the Canadian Shield (Rolandon et al. 2003; Chouinard and Mareschal 2009). Rather higher variability of the ice base temperature in Late Pleistocene has been reported for other parts of the Northern America (Gosnold et al. 2005; Chouinard and Mareschal 2009; Perry et al. 2009; Gosnold et al. 2011), but generally it is lower than the variability observed in Eurasia (Šafanda et al. 2004; Šafanda and Rajver 2001; Demezhko et al. 2007; Mottaghy et al. 2010; Majorowicz and Wybraniec 2011). Also, present cold-base ice in Greenland has been measured at $-8.4{ }^{\circ} \mathrm{C}$ for the $\log$ GRIP and $-13.2{ }^{\circ} \mathrm{C}$ for Dye-3 (Dahl-Jensen et al. 1998; Demezhko et al. 2007). 


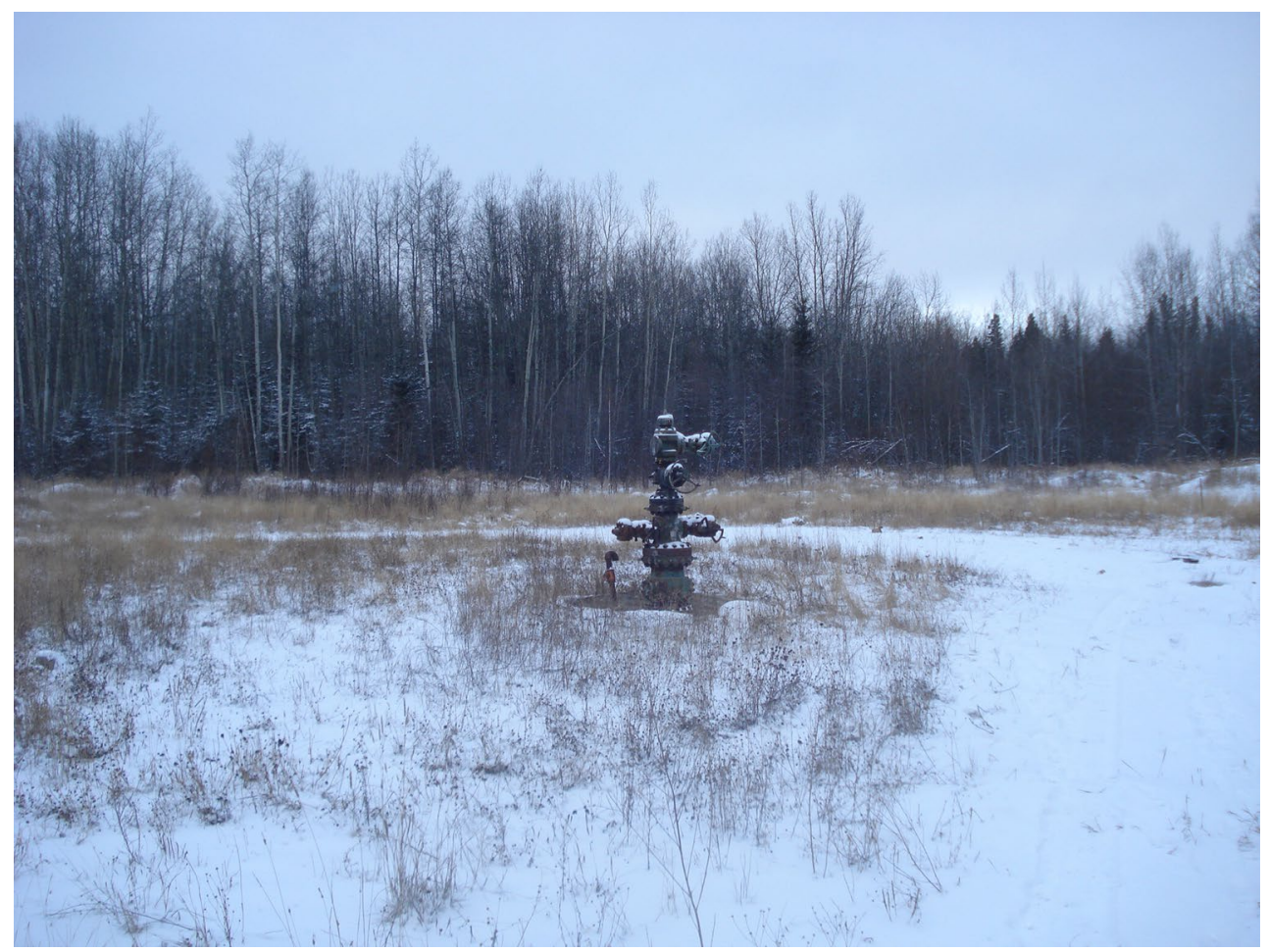

Fig. 2 Hunt well head site in northeastern Alberta clear cut in the borealis forest environment
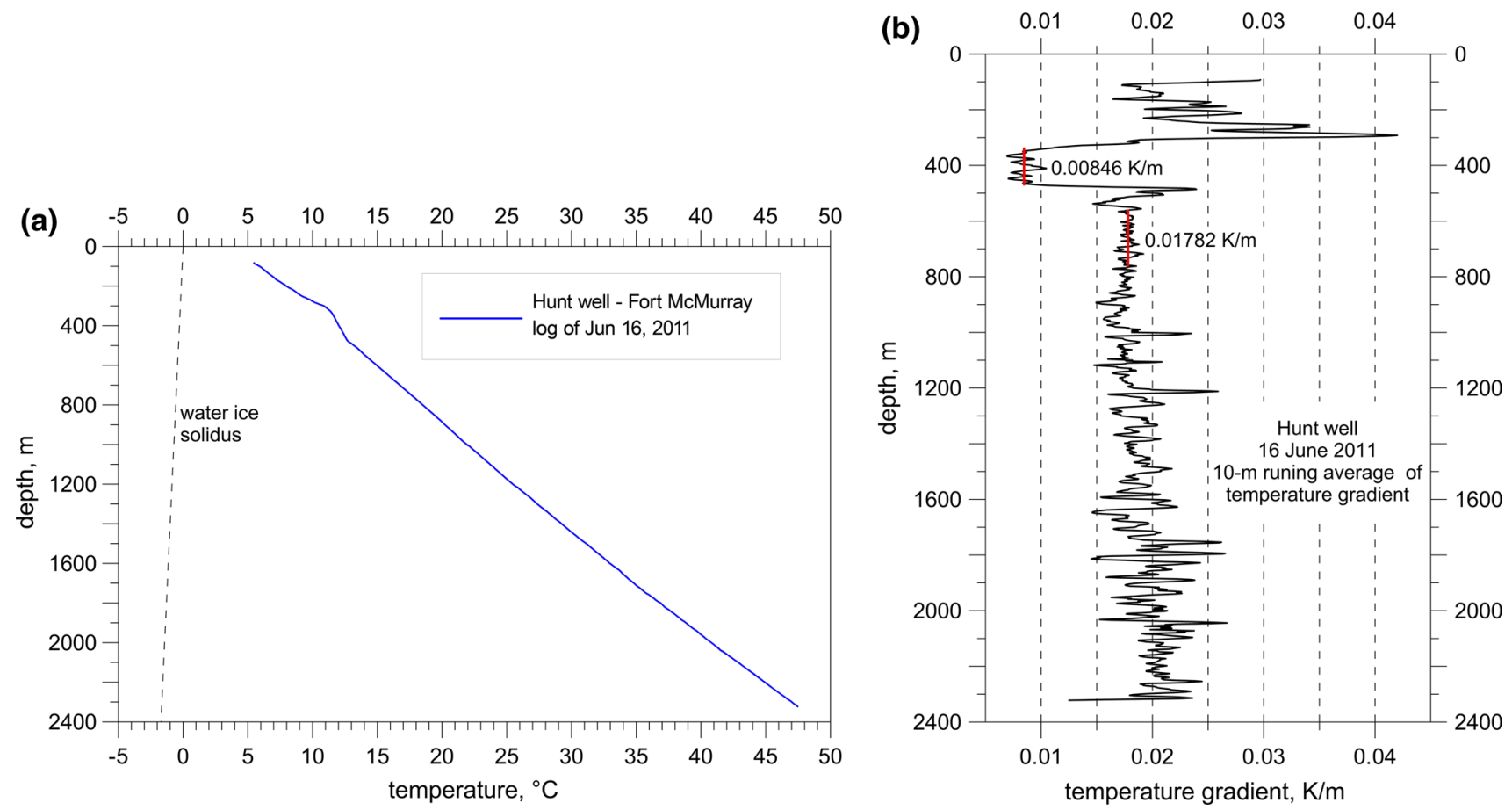

Fig. 3 a Precise equilibrium condition temperature versus depth temperature continuous logs in wells AOC GRANITE 7-32-89-10, hereafter referred to as the Hunt well in equilibrium condition $(\log 6$ of June 2011). b Geothermal gradient versus depth. Notice the contrast between the low gradient layer around $400 \mathrm{~m}$ (gradient $0.00846 \mathrm{~K} / \mathrm{m}$ ) and the uppermost part of the granite (gradient $0.01782 \mathrm{~K} / \mathrm{m}$ ) (see the text) 
The perturbation to heat flow with depth will be much stronger for the cold-base ice like in Greenland or northern Eurasia (Dahl-Jensen et al. 1998 and Demezhko et al. 2007) than warm base glaciers likely the case of Canada (Chouinard and Mareschal 2009). The amplitude of such temperature change will depend upon temperatures at the base of the glacier and the present ambient temperature. Also, geothermal gradient in present ice-free areas will be affected to a depth of approximately 1.5-2.2 km (Kukkonen 1993; Šafanda et al. 2004; Majorowicz and Wybraniec 2011; Rath et al. 2012).

\section{Functional space inversion of Hunt well temperature data}

The method of preference used in reconstructing the ground surface temperature (GST) history from the Hunt well profile is the FSI, which was proposed and published by Beck et al. (1992) and Shen and Beck (1992). This Bayesian method (see Tarantola and Valette 1982a, 2b) requires, beside the measured temperature-depth profile, an a priori estimate of the geothermal subsurface model, which is assumed to be one dimensional and purely conductive, and the a priori estimate of the GST history. In order not to bias the results, the a priori estimate of the GST history is usually a constant (no GST variations). All these parameters are treated as random quantities with their a priori standard deviations and the method provides their a posteriori estimates.

The Hunt well stabilized profile was measured in June 2011 to the depth of $2,320 \mathrm{~m}$. The first attempt to reconstruct the GST history from this log was published by Majorowicz et al. (2012a) and is commented in "Upward extrapolation of the close-to-steady-state part of the temperature log" section.

The new reconstruction of surface temperature history has been done in this paper based on newer data (Majorowicz et al. 2014). Spectral gamma logs allowed Majorowicz et al. (2014) reconstruction of heat production with depth. The new heat production model $\left(0.67 \mu \mathrm{W} / \mathrm{m}^{3}\right.$ in sediments, $3.52 \mu \mathrm{W} / \mathrm{m}^{3}$ between 500 and $1,500 \mathrm{~m}$ and $2.25 \mu \mathrm{W} / \mathrm{m}^{3}$ below).

The FSI inversion of the Hunt well $T-z$ profile was done for the following a priori geothermal model:

Heat production

$$
\begin{aligned}
& 0-500 \mathrm{~m} 0.67 \mu \mathrm{W} / \mathrm{m}^{3} \\
& 500-1,500 \mathrm{~m} 3.52 \mu \mathrm{W} / \mathrm{m}^{3} \\
& 1,500-12,000 \mathrm{~m} 2.25 \mu \mathrm{W} / \mathrm{m}^{3}
\end{aligned}
$$

Thermal conductivity Thermal conductivity of granitic body encountered below $550 \mathrm{~m}$ is based on measurements done on the drill-core samples. Their ambient condition measured average value, $2.72 \mathrm{~W} /(\mathrm{m} \mathrm{K}$ ) (Majorowicz et al. 2014) was used as a value $\mathrm{k}_{\mathrm{o}}$ characterizing the rock at room conditions, i.e., at the atmospheric pressure and temperature of $20^{\circ} \mathrm{C}$. To estimate an a priori thermal conductivity model, we used the formula of Chapman and Furlong (1992)

$k(z, T)=k_{o} *(1+c * z) /(1+b *(T-20))$,

which yields the in situ values assuming their dependence on pressure (depth) and temperature measured at the given depth. The adopted values of the coefficients in the formula (1) were $c=1.5 * 10^{-6} \mathrm{M}^{-1}, b=1.5 * 10^{-3} \mathrm{~K}^{-1}$, the typical values for the upper crust (Chapman and Furlong 1992).

There were no drill-core samples available from the sedimentary cover above the granite, i.e., above $550 \mathrm{~m}$, for the thermal conductivity measurements. The lithological profile (Majorowicz et al. 2014) indicates three main layers - sand $(0-150 \mathrm{~m})$, limestone $(150-400 \mathrm{~m})$, and anhydrite (below $400 \mathrm{~m}$ ). This quite heterogenous lithology together with a broad spread of conductivity values given for the individual rock types in the literature (Čermák and Rybach 1982) does not allow for a reliable estimate of the conductivity profile above $550 \mathrm{~m}$. As a consequence, the effects of thermal conductivity variations and of the GST changes on the temperature profile curvature (Fig. 3a) cannot be reliably distinguished. That is why the uppermost part of the temperature $\log$ above $550 \mathrm{~m}$ was not considered in the FSI inversion. The only feature evidently related to the lithology is a sharp decrease of the gradient in the section 340-470 m, where its value attains $8.46 \mathrm{mK} / \mathrm{m}$ (Fig. 3b). This section overlaps with the occurrence of anhydrite, the thermal conductivity of which can be up to $6 \mathrm{~W} /(\mathrm{m} \mathrm{K}$ ) (Čermák and Rybach 1982). We tried to estimate in situ conductivity of this layer by comparing its temperature gradient with the gradient of the uppermost part of the granite body between 560 and $760 \mathrm{~m}$ amounting to $17.82 \mathrm{mK} / \mathrm{m}$. Under the approximate assumption of the same heat flow in the two depth sections and thermal conductivity of the deeper one $2.73 \mathrm{~W} /(\mathrm{m} \mathrm{K})$, the in situ conductivity of the anhydrite layer was estimated at $5.75 \mathrm{~W} /(\mathrm{m} \mathrm{K})$. Conductivity of the rest of the sedimentary cover was kept at $2.7 \mathrm{~W} /$ (m K). Diffusivity was estimated at $2.5 * 10^{-6} \mathrm{~m}^{2} / \mathrm{s}$ for the layer $340-470 \mathrm{~m}$ and $1.2-1.4 * 10^{-6} \mathrm{~m}^{2} / \mathrm{s}$ outside it.

The remaining two quantities, namely the heat flow at the bottom of the model (at the depth of $4 \mathrm{~km}$ ) and the surface temperature $100 \mathrm{kyr}$ ago at the beginning of the reconstructed time interval, are very well resolved by the data, and their a priori estimate can be very rough $( \pm 100 \mathrm{~mW} /$ $\mathrm{m}^{2}$ and $\left.\pm 10 \mathrm{~K}\right)$.

The a priori estimate of the surface temperature history assumed no variations. This conservative approach prevents a possible bias in the results and guarantees that the reconstructed changes are fully determined by the data. The depth step of the selected $T-z$ measurements used in the inversion 


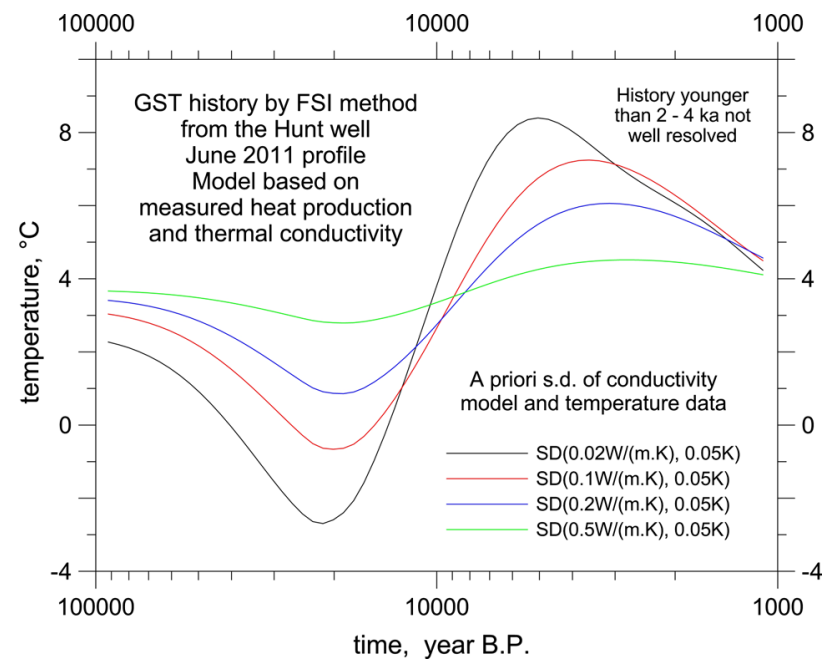

Fig. 4 The 100 kyr of the surface temperature history reconstructed from Hunt well temperature profile (550-2,320 m) for four different values of thermal conductivity standard deviation

was $20 \mathrm{~m}$. The time steps at which the GST history was reconstructed increased logarithmically into the past.

The critical parameter of the inversion, beside the measured $T-z$ profile, is the a priori estimate of thermal conductivity model and its standard deviation. The results of the inversion for the last $100 \mathrm{kyr}$ (Fig. 4) depend strongly on the chosen standard deviation. With the increasing standard deviation, the inversion has a tendency to "explain" the curvature of the measured $T-z$ profile more and more as a result of decreasing thermal conductivity with depth rather than the transient features caused by the surface temperature changes. With increasing value of SD (from $0.02 \mathrm{w} /$ (m k) via $0.1,0.2$ to $0.5 \mathrm{~W} /(\mathrm{m} \mathrm{K})$ ), the history reconstructed for the last $100 \mathrm{kyr}$ becomes flatter, because the inversion algorithm interprets more and more the temperature-depth profile curvature as a result of the conductivity changes rather than as a result of the surface temperature variations. It is evident from Fig. 5, where the a posteriori conductivitydepth profiles corresponding to the individual a priori SD of conductivity are depicted below $500 \mathrm{~m}$. It is clear that only the lowest considered SD of $0.02 \mathrm{~W} /(\mathrm{m} \mathrm{K})$ leads to a posteriori conductivity profile, which is close to the a priori one. The higher SD values yield a posteriori profiles of strongly decreasing conductivity with increasing depth. However, the a posteriori conductivity above $500 \mathrm{~m}$ (not shown) is very close to the a priori one for all values of $\mathrm{SD}$, because that depth section is not resolved in the inversion. Because the mineralogy study (Walsh 2013) gives no reason to assume a systematic change of thermal conductivity with depth in the monotonous granite, and measured conductivity in two independent levels at around 1,600 and 2,300 $\mathrm{m}$ is not different (Majorowicz et al. 2014), we believe that the GST histories corresponding to the low a priori SD. Conductivity

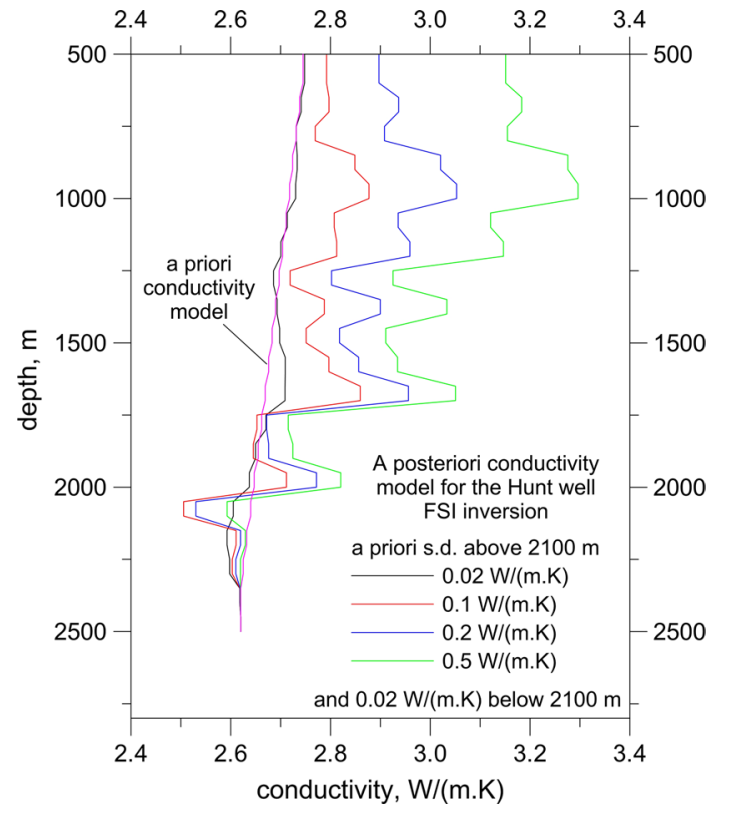

Fig. 5 A priori and a posteriori conductivity profiles for the individual standard deviations and their comparison with the a priori model

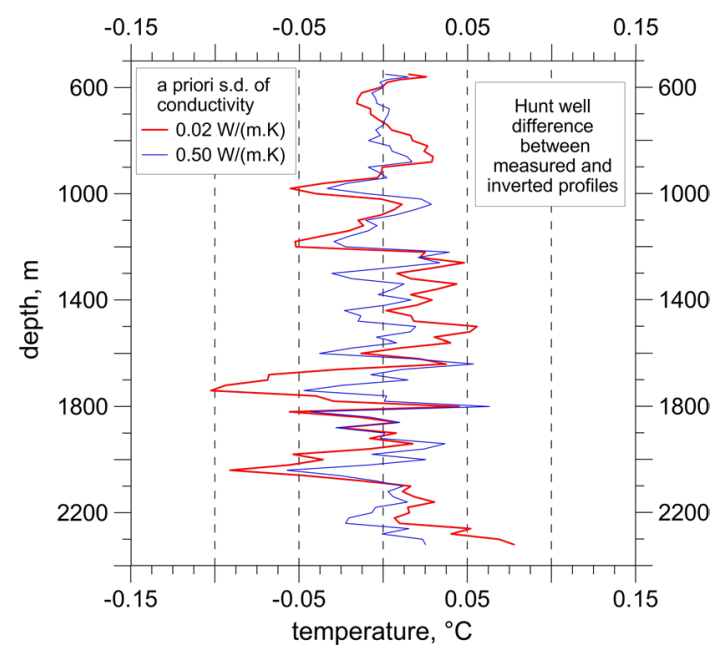

Fig. 6 Difference between the a priori (measured) $T-z$ profile and the a posteriori one (corresponding to the reconstructed ground surface temperature history and a posteriori thermal conductivity model) for two values of a priori SD of thermal conductivity, 0.02 and $0.50 \mathrm{~W} /$ (m K)

model is more realistic than that for higher SD values. Another argument for considering the results obtained by low a priori SD of conductivity as more realistic is the fact that the GST reconstructed for the last glacial maximum, when the Hunt well site was covered by ice sheet, is below zero only for SD lower than $0.2 \mathrm{~W} /(\mathrm{m} \mathrm{K})$.

The GST history (Fig. 4) yielded by the inversion with a priori SD of conductivity $0.02 \mathrm{~W} /(\mathrm{m} \mathrm{K})$ exhibits a minimum 
of about -2 to $-3{ }^{\circ} \mathrm{C}$ during the last glacial maximum (20$25 \mathrm{kyr}$ ago) and a maximum of $8-9^{\circ} \mathrm{C}$ for the time $5 \mathrm{kyr}$ ago. The GST history younger than $4 \mathrm{kyr}$ [for a priori SD $0.02 \mathrm{~W} /(\mathrm{m} \mathrm{K})]-2 \mathrm{kyr}$ [for a priori SD $0.5 \mathrm{~W} /(\mathrm{m} \mathrm{K})$ ] is poorly resolved because maximum of its subsurface signal is contained in the upper 500 m (Šafanda and Rajver 2001) of the temperature log that have not been considered in the inversion. Having no climatic signal for this period, the inversion returns the prior values, i.e., the surface temperatures reconstructed for time $100 \mathrm{kyr}$ ago. However, the temporal resolution of the GST history decreases going back in time (e.g., Claw 1992), and the temperature reconstructed for time $100 \mathrm{kyr}$ ago represents an average over tens of thousands of years.

Difference between the a priori (measured) $T-z$ profile and the a posteriori one (corresponding to the reconstructed GST history and a posteriori thermal conductivity model) for two values of a priori $\mathrm{SD}$ of thermal conductivity, 0.02 and $0.50 \mathrm{~W} /$ $(\mathrm{m} \mathrm{K})$, is shown in Fig. 6. The residuum is generally smaller for the higher SD value, when the inversion algorithm uses a higher degree of freedom for adjusting conductivity model to small-scale variations of temperature gradient. The difference is mostly within $0.05 \mathrm{~K}$, which is the assumed a priori SD of the measured $T-z$ profile and does not exceed $0.11 \mathrm{~K}$.

\section{Upward extrapolation of the close-to-steady-state part of the temperature $\log$}

As mentioned above, the first estimate of the last ice age surface temperatures at the Hunt well site was published by Majorowicz et al. (2012a). It was done by an upward extrapolation of the Hunt well temperature log from the depth of 2,250 $\mathrm{m}$ to the surface. This approach is based on the assumption that the temperature log below $2 \mathrm{~km}$ is close to the steady-state corresponding to the long-term surface temperature. The climate of the last $1 \mathrm{Myr}$ is characterized by a sequence of approximately 100-kyr-long glacial cycles consisting typically of a long cold glacial and a short-warm interglacial period. As our previous numerical simulations showed (Šafanda et al. 2004; Majorowicz et al. 2012b), after the repetition of five and more identical $100 \mathrm{kyr}$ glacial cycles, the upward extrapolation of synthetic temperature logs (taken at the present phase of the glacial cycle some 10-15 kyr after the end of its cold part) from the depth below $2 \mathrm{~km}$ yields surface temperature that falls into a narrow interval constrained from below by the mean of the cold part of the $100 \mathrm{kyr}$ cycle and from above by the mean of the whole $100 \mathrm{kyr}$ cycle. Therefore, the extrapolation represents an alternative, and on the FSI method independent, approach for estimation the average glacial conditions of several last $100 \mathrm{kyr}$ cycles. The preliminary geothermal model used by Majorowicz et al. (2012a) yielded the extrapolated surface temperatures in the interval $\left(-4,-5{ }^{\circ} \mathrm{C}\right)$.

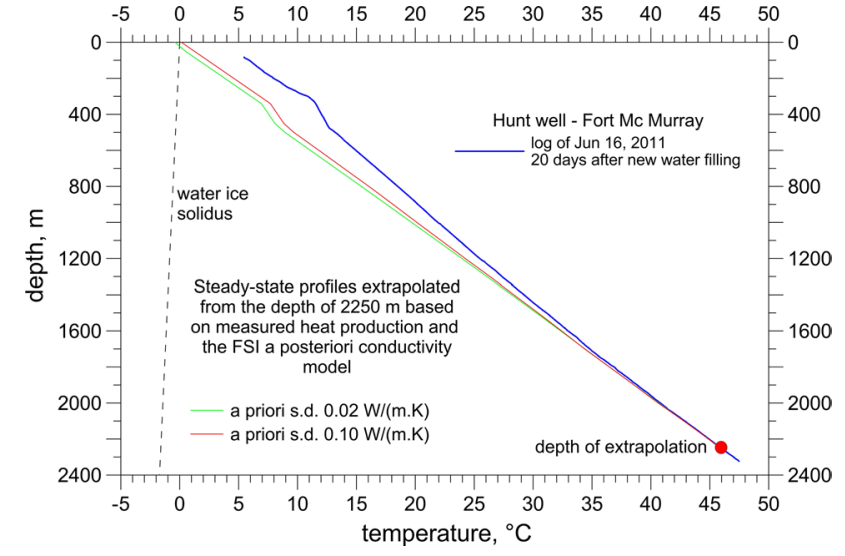

Fig. 7 Extrapolations of the close-to-steady-state $T-z$ profiles from the depth of 2,250 m based on the new heat production model $\left(0.67 \mu \mathrm{W} / \mathrm{m}^{3}\right.$ in sediments, $3.52 \mu \mathrm{W} / \mathrm{m}^{3}$ between 500 and $1,500 \mathrm{~m}$ and $2.25 \mu \mathrm{W} / \mathrm{m}^{3}$ below) and the a posteriori FSI conductivity model for SD 0.02 and $0.5 \mathrm{~W} /(\mathrm{m} \mathrm{K})$ (Fig. 5), respectively. Heat flow below $2.2 \mathrm{~km}$ is $51 \mathrm{~mW} / \mathrm{m}^{2}$

We show (Fig. 7) the new extrapolations of the $T-z$ profiles from the depth of $2,250 \mathrm{~m}$ based on the new heat production model (the same as used in the FSI inversion described above) and on the a posteriori FSI conductivity model for SD $0.02 \mathrm{~W} /(\mathrm{m} \mathrm{K})$ and $0.1 \mathrm{~W} /(\mathrm{m} \mathrm{K})$. The new extrapolation yields higher surface temperatures of -0.4 and $+0.1{ }^{\circ} \mathrm{C}$ for SD 0.02 and 0.1 , respectively, than the old model of Majorowicz et al. (2012a) that was based on assumed values and did not consider the high conductivity layer between 340 and $470 \mathrm{~m}$. If we interpret the extrapolated surface temperature as the mean temperature of several last $100 \mathrm{kyr}$ glacial cycles and assume that it represents a weighted average of the cold glacial part lasting $75 \mathrm{kyr}$ and of the warm interglacial part lasting $25 \mathrm{kyr}$, we can estimate the mean temperature of the cold part. Doing so, we considered the present GST of $5{ }^{\circ} \mathrm{C}$ as a representative value of the interglacial part. Then, the mean of the 75-kyrlong glacial part amounts to -2.2 and $-1.5^{\circ} \mathrm{C}$ for SD 0.02 and 0.1 , respectively. Alternatively, if we assume that the extrapolated surface temperature represents a mean of the cold part itself, the estimate of the mean last ice age surface condition is -0.4 and $+0.1{ }^{\circ} \mathrm{C}$ for SD 0.02 and 0.1 , respectively, and the mean of the whole $100 \mathrm{kyr}$ cycle is +1.0 and $+1.3{ }^{\circ} \mathrm{C}$. Taken altogether, our estimate of the mean surface temperature of the cold part of the glacial cycle is between -2 and $0{ }^{\circ} \mathrm{C}$, the mean of the whole $100 \mathrm{kyr}$ cycle in the interval -0.5 and $+1{ }^{\circ} \mathrm{C}$ and the minimum temperature during the last glacial maximum up to $-3{ }^{\circ} \mathrm{C}$ (Fig. 8).

The results of both the FSI inversion and the upward extrapolation indicate that the permafrost probably existed at the Hunt well site during the cold part(s) of the glacial cycle. If we consider the minimum surface temperature yielded by the FSI as $-3{ }^{\circ} \mathrm{C}$ (Fig. 4), surface heat flow of 
Fig. 8 Comparison of 3 cases of the glacial base temperature. Hunt AOC Anhydride N. Canada well derived paleotemperature $-1{ }^{\circ} \mathrm{C}$ (this study); Udryn-Krzemianka paleotemperature NE Poland $\left(-10^{\circ} \mathrm{C}\right.$; Šafanda et al. (2004) FSI-based estimate supported by finding of relic permafrost there by Szewczyk and Nawrocki (2011) and present Greenland's $\left(-13{ }^{\circ} \mathrm{C}\right.$ Dahl-Jensen 1998)

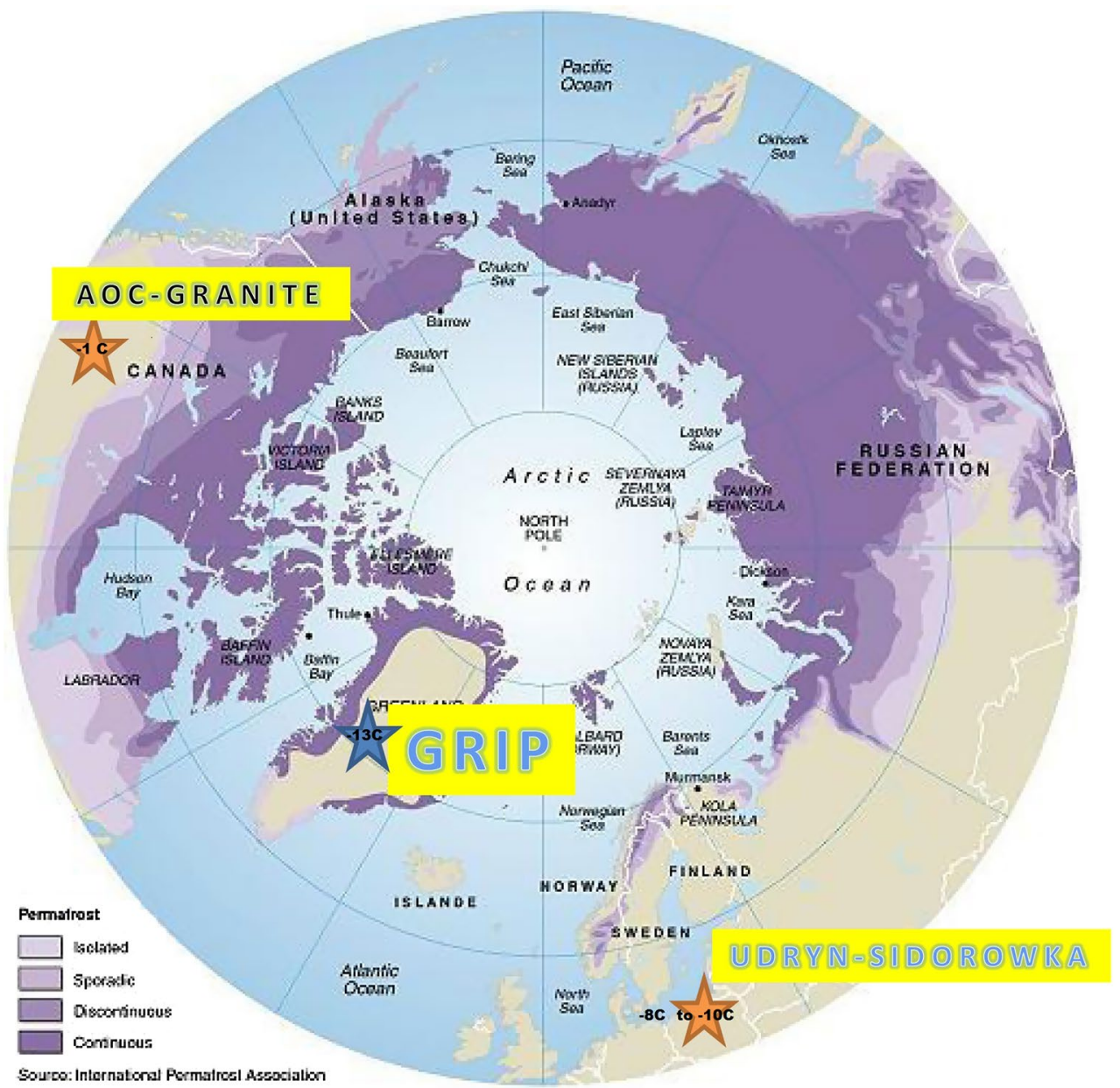

$60 \mathrm{~mW} / \mathrm{m}^{2}$ and thermal conductivity of the frozen rock $4 \mathrm{~W} /(\mathrm{m} \mathrm{K})$ (estimated as conductivity of unfrozen sediments $2.7 \mathrm{~W} /(\mathrm{m} \mathrm{K})$ multiplied by a factor of 1.5 (Lachenbruch and Marshall 1986) corresponding to the typical range of sandy sediments porosity $25-30 \%$ ), the maximum depth of the permafrost base can be estimated at $200 \mathrm{~m}$. It means that the downward propagation of the surface temperature changes was influenced by effects of the release/ consumption of the latent heat during freezing/thawing of the interstitial water/ice within sediments. Ignoring this process in the FSI inversion (the FSI method does not allow for considering it) might have dampened the reconstructed glacial/interglacial surface temperature amplitude. However, the $T-z$ profile below $2 \mathrm{~km}$ is adjusted to the longterm surface temperature mean and mostly unaffected by the latent heat effect.

\section{Conclusions}

The new estimates of the paleotemperatures obtained from the Hunt well temperature log by FSI inversion and by the upward extrapolation from the depth of 2,250 $\mathrm{m}$ are quite consistent, but by $2-3 \mathrm{~K}$ higher than the previous preliminary estimates by Majorowicz et al. (2012a). They indicate that the average surface temperature of the $100 \mathrm{kyr}$ glacial cycles is around $0{ }^{\circ} \mathrm{C}$, the average of their glacial part up to $-2{ }^{\circ} \mathrm{C}$ and the minimum values reached during the last glacial maximum some $20 \mathrm{kyr}$ ago could be as low as $-3{ }^{\circ} \mathrm{C}$. The temperature amplitude between the last glacial maximum and Holocene Optimum might amount to 10-12 K. These results for the Northern Alberta part of the Laurentide Ice Sheet generally agree with other evidence on paleotemperatures at the base of this ice sheet inferred from borehole temperature data from wells to the east in Manitoba, Ontario and parts of western Quebec, Canada (Rolandon et al. 2003). This is in great contrast to paleotemperatures at the base of the glaciation in Europe and parts of Asia where temperatures as low as -10 to $-20{ }^{\circ} \mathrm{C}$ have been reported (Demezhko et al. 2007; Šafanda et al. 2004) more in accordance with those presently recorded under existing glacial ice in Greenland $\left(-13{ }^{\circ} \mathrm{C}\right.$; Dahl-Jensen et al. 1998). This difference between warm base paleoglacial in Canada versus cold-base one in Greenland and Eurasia is difficult to explain, and it is not the scope of this paper. However, this interesting observation warrants farther 
investigation from hopefully new evidence from new deep drilling below $2 \mathrm{~km}$ on both continents.

Acknowledgments We would like to thank Charles Warren Hunt for allowing HAI4 (Helmholtz-Alberta Initiative program at the University of Alberta first author works for) to log his well (Hunt Well). We would like to thank HAI, and especially theme 4 "Geothermal Energy" research coordinators Prof. Martyn Unsworth (UofA Edmonton) and Prof. Ernst Huenges (GFZ Potsdam), for enabling such an in depth study which increased our knowledge on the geothermal energy potential in the area. The support to the second author Dr. Jan Safanda was provided by the Grant Agency of the Czech Republic (project GACR P210/11/0183).

\section{References}

Beck AE, Shen PY, Beltrami H, Mareshal J-C, Šafanda J, Sebagenzi MN, Vasseur G, Wang K (1992) A comparison of five different analyses in the interpretation of five borehole temperature data sets. Global Planet Change 98:101-112

Bodri L, Čermák V (2007) Borehole climatology—a new method on how to reconstruct climate. Elsevier, Amsterdam

Campbell C (1998) Late Holocene lake sedimentology and climate change in southern Alberta, Canada. Quat Res 49:96-101

Čermák V (1971) Underground temperature and inferred climatic temperature of the past millennium. Palaeogeogr Paleoecclimatol Paleoecol 10:1-19

Čermák V, Rybach L (1982) Thermal conductivity and specific heat of minerals and rocks. In: Angenheister G (ed) Landolt-Bornstein, Physical properties of rocks, vol 5/1a. Springer, Berlin, p 305

Chapman DS, Furlong KP (1992) Thermal state of the lower continental crust. In: Fountain DM, Arculus R, Kay R (eds) Continental lower crust. Elsevier, Amsterdam, pp 179-199

Chouinard C, Mareschal J-C (2009) Ground surface temperature history in southern Canada: temperatures at the base of the Laurentide ice sheet and during the Holocene. Earth Planet Sci Lett 277:280-289

Claw GD (1992) The extent of temporal smearing in surface-temperature histories derived from borehole temperature measurements. Global Planet Change 6:81-86

Dahl-jensen D, Mosegaard K, Gundestrup N, Clow GD, Johnsen SJ, Hansen AW, Balling N (1998) Past temperature directly from the greenland ice sheet. Science 282:268-271

Demezhko DYu, Golovanova IV (2007) Climatic changes in the urals over the past millennium - an analysis of geothermal and meteorological data. Clim Past 3:237-242

Demezhko DY, Ryvkin DG, Outkin VI, Duchkov AD, Balobaev VT (2007) Spatial distribution of pleistocene/holocene warming amplitudes in northern eurasia inferred from geothermal data. Clim Past 3:559-568

Demezhko DYu, Gornostaeva AA, Tarkhanov GV, Esipko OA (2013) 30,000 Years of ground surface temperature and heat flux changes in karelia reconstructed from borehole temperature data. Bull Geogr Phys Geogr Ser 6:7-25

Gosnold WD, Majorowicz J, Šafanda J, Szewczyk J (2005) Has northern hemisphere heat flow been underestimated? American Geophysical Union, Spring Meeting, 23-27 May 2005, New Orleans, LA, abstract \#T43D-01

Gosnold W, Majorowicz J, Klenner R, Hauk S (2011) Implications of post-glacial warming for northern hemisphere heat flow. GRC Trans 35:795-800

Grove J (1988) The little ice age. Methuen \& Co, London
Hotchkiss WO, Ingersoll LR (1934) Post-glacial time calculations from recent geothermal measurements in the Calumet copper mines. J Geol 42:113-142

IPCC (2007) Summary for policymakers In: Solomon S, Qin D, Manning M, Chen Z, Marquis M, Averyt DB, Tignor M, Miller HL (eds) Climate Change 2007: The physical science basis. Cambridge University Press, Cambridge

Jessop A (1971) The distribution of glacial perturbation of heat flow in Canada. Can J Earth Sci 8:162-166

Kerwin M, Overpeck JT, Webb RS, Devernal A, Rind DH, Healy RJ (1999) The role of oceanic forcing in mid-holocene northern hemisphere climatic change. Paleoceanography 14:200-210

Kukkonen IT (1993) Heat flow map of northern and central parts of the fennoscandian shield based on geochemical surveys of heat producing elements. Tectonophysics 225:3-13

Kukkonen IT, Joeleht A (2003) Weichselian temperatures from geothermal heat flow data. J Geophys Res 108(B3):2163. doi:10.10 29/2001JB001579

Kukkonen IT, Šafanda J (1996) Palaeoclimate and structure: the most important factors controlling subsurface temperatures in crystalline rocks. A case study from Outokumpu, eastern Finland. Geophys J Int 126:101-112

Kukkonen IT, Gosnold WD, Šafanda J (1998) Anomalously low heat flow density in eastern Karelia, Baltic Shield: a possible paleoclimate signature. Tectonophysics 291:235-249

Lachenbruch AH, Marshall BV (1986) Changing climate: geothermal evidence from permafrost in Alaska. Science 234:689-696

Lamb HH (1965) The early medieval warm epoch and its sequel. Palaeogeogr Paleoecclimatol Paleoecol 1:13-37

Luckman BH, Wilson RJS (2005) Summer temperatures in the Canadian Rockies during the last millennium: a revised record. Clim Dyn 24:131-144

Luckman BH, Briffa KR, Jones PD, Schwaingruber FH (1997) Tree ring based reconstruction of summer temperatures at the Columbia Icefield. Alberta, Canada, AD 1073-1983. Holocene 7:375-389

Majorowicz J, Šafanda J (2008) Heat flow variation with depth in Poland: evidence from equilibrium temperature logs in $2.9-\mathrm{km}-$ deep well Torun-1. Int J Earth Sci 97:307-315. doi:10.1007/ S00531-007-0210-2

Majorowicz J, Wybraniec S (2011) New terrestrial heat flow map of Europe after regional paleoclimatic correction application. Int $\mathrm{J}$ Earth Sci 100(881-887):55

Majorowicz J, Gosnold W, Gray A, Šafanda J, Klenner R, Unsworth M (2012a) Implications of post-glacial warming for northern Alberta heat flow- correcting for the underestimate of the geothermal potential. GRC Trans 36:693-698

Majorowicz J, Šafanda J, Osadetz K (2012b) Inferred gas hydrate and permafrost stability history models linked to climate change in the Beaufort-Mackenzie Basin. Arctic Clim Past 8:667-682

Majorowicz J, Chan J, Crowell J, Gosnold W, Heaman LM, Kück J, Nieuwenhuis G, Schmitt DR, Unsworth MJ, Walsh N, Weides S (2014) The first deep heat flow determination in crystalline basement rocks beneath the Western Canadian Sedimentary Basin. Geophys J Int. online, doi:10.1093/gji/ggu065)

Mareschal J-C, Rolandone F, Bienfait G (1999) Heat flow variations in a deep borehole near Sept-Iles, Québec, Canada: paleoclimatic interpretation and implications for regional heat flow estimates. Geophys Res Lett 26:2049-2052

Mottaghy D, Majorowicz J, Rath V (2010) Ground surface temperature histories reconstructed from boreholes in Poland: implications for spatial variability. In: Przybylak R, Majorowicz J, Brázdil R, Kejna M (eds) The Polish Climate in the European Context An Historical Overview, Chapter 27:375-389. Springer, Berlin 
Peltier WR (2002) Global glacial isostatic adjustment: paleogeodetic and space geodetic tests of the ICE-4G(VM2) model. J Quat Sci 17:491-510. doi:10.1002/JQS.713,2002

Perry HKC, Mareschal J-C, Jaupart C (2009) Enhanced crustal geoneutrino production near the Sudbury neutrino observatory, Ontario, Canada. Earth Planet Sci Lett 288(1-2):301-308

Pollack HN, Huang S, Shen P-Y (1998) Climate change record in subsurface temperatures: a global perspective. Science 282:279-281

Rath V, González Rouco JF, Goosse H (2012) Impact of postglacial warming on borehole reconstructions of last millennium temperatures. Clim Past 8:1059-1066

Ritchie JC (1983) The paleoecology of the central and northern parts of the glacial lake agassiz basin. Geol Assoc Can Spec Pap 26:157-170

Rolandone F, Mareschal JC, Jaupart C (2003) Temperatures at the base of the Laurentide Ice Sheet inferred from borehole temperature data. Geophys Res Lett 30(18):1944

Šafanda J, Rajver D (2001) Signature of the last ice age in the present subsurface temperatures in the Czech Republic and Slovenia. Global Planet Change 29:241-257
Šafanda J, Szewczyk J, Majorowicz J (2004) Geothermal evidence of very low glacial temperatures on a rim of the Fennoscandian ice sheet. Geophys Res Lett 31:L07211. doi:10.1029/2004GL019547

Shen PY, Beck AE (1992) Paleoclimate change and heat flow density inferred from temperature data in the Superior Province of the Canadian Shield. Global Planet Change 6:143-165

Szewczyk J, Nawrocki J (2011) Deep-seated relict permafrost in northeastern poland. Boreas, Online. doi:10.1111/J.1502-3885.2011.00218.X

Tarantola A, Valette B (1982a) Generalized nonlinear inverse problems solved using the least squares criterion. Rev Geophys Space Phys 20:219-232

Tarantola A, Valette B (1982b) Inverse problems = quest for information. J Geophys Res 50:159-170

Walsh NJ (2013) Geochemistry and geochronology of the Precambrian Basement Domains in the Vicinity of Fort McMurray, Alberta: A Geothermal Perspective, M.Sc. Thesis, University of Alberta, 194 pp 